\title{
ASSESSMENT OF IRRIGATION POTENTIALITY OVER AN AREA THROUGH THE COMBINED APPLICATION OF REMOTE SENSING (RS) AND GEOGRAPHIC INFORMATION SYSTEM (GIS)
}

\author{
Md. Abdus Salam*, Farhana Tazneen, Md. Shafiqul Islam and S. M. Noman Chy. \\ Bangladesh Space Research and Remote Sensing Organization, Agargaon, Dhaka-1207, Bangladesh
}

Received: 08 July 2020

Accepted: 11 December 2020

\begin{abstract}
There is a great influence of irrigated land of an area to the acreage and productions of agricultural crops and thus maintain the food security. Recent awareness about climate change and its impacts on global environmental challenges has drawn the great attention on rational and sustainable handling of irrigation resources and its networks. As one of the cutting-edge technologies remote sensing data and geographical information system (GIS) are very much useful for efficient management of irrigation networks and optimum utilization of irrigation schemes for the sustainable agricultural development. Irrigation potentiality is the total area which can be irrigated from a project on its full utilization. This implies that an area where water is available for irrigation in each season during a complete irrigation year. In the present study an attempt has been made to investigate the irrigation potentiality of an area using remote sensing data as primary source and field data and as well as ground water level data from secondary source. Landsat 8 OLI (Operational Land Imager) data of 2016 and 2017 have been used for this purpose. Existing irrigation system has also been identified through the investigation of natural and artificial sources of irrigation water of the study area. Seasonal irrigated area was also monitored during the crop growing season. Ground water level fluctuation was also studied using ancillary data.
\end{abstract}

Keywords: GIS; Irrigation potentiality; Mapping; Monitoring; Remote Sensing.

\section{INTRODUCTION}

In Bangladesh only about $47.39 \%$ of total cropped is cultivated under irrigation (BBS 2015) and the major portion is cultivated under rain-fed conditions, either with, or without a drainage system. Among the cultivated crops, rice occupies about $75.08 \%$ of total cropped areas (BBS 2015). In 2015-16 total irrigated area was 7448 thousand hectares which is $48.24 \%$ of total cropped area (15438 thousand hectares). In 2015-16 Boro rice area is 11794 thousand acres which is $30.92 \%$ of total cropped area (38148 thousand acres). In 2015-16 Boro rice area is 11794 thousand acres which is $64.08 \%$ of total irrigated area (18405 thousand acres) (BBS 2017). In quite some cases the irrigation system/pattern is not well planned, that is why cultivation of agricultural crops in such areas is hampering. Water supply for irrigation purposes has played a vital role for increasing the crop acreage and production as well. Sustainable and cost-effectiveness irrigation facilities enhance the reliability of the water supply to the farmers (Sarker et al., 2011). Position of the poor on the poverty scale is substantially determined by the difficulties of having access to water (Islam and Akman, 2007). The development of remote sensing techniques has greatly improved our capability to monitor land surface processes. Specifically, large field of view Satellites are able to observe the entire planet on a daily basis (NOAA), or even more frequently (METEOSAT, GOES). Other more specialized Satellites offer a greater spatial or spectral resolution but have a less frequent coverage (IRS, SPOT, Landsat), and can be used to support detailed studies on smaller areas. A good knowledge of the geographical space and related spatial information like water sources, watershed, terrain surface, land use, land cover, rainfall, temperature, humidity, soil condition and composition, geology, conditions on the atmosphere, human activities, environmental data, etc. are important for water management (Gebeyehu, 2019). For irrigation water management remote sensing and GIS are viewed as an efficient tool. Under different climatic and operational conditions, GIS and remote sensing techniques can provide managers and planners with the visualizing effects resulting from various management strategies (Mohammadi, 2019). Traditionally irrigation performance is evaluated based on point measurements. With recent developments in remote sensing and GIS techniques have made it possible to assess scheme-wide performance on a pixel-bypixel basis (Taghvaeian, 2018).

Still groundwater is mostly used source of water used for irrigation. Different thematic layers like land use/land cover (LULC), rainfall, geomorphology, drainage density, lineament density, lithology, slope etc. could be considered as important parameters to delineate groundwater potentiality of an area (Rahman et al., 2018). An attempt was made to calculate the Irrigation water quality index (IWQI) for groundwater samples collected from randomly assigned boreholes and tube wells in the south western part of Bangladesh (Hasana et al., 2020). In the proposed study the irrigation potentiality over an agricultural area will be assessed using remote sensing and 
GIS techniques. The study will provide the means to make an inference for suitable irrigation system/pattern and water use planning. The study will also provide recommendations for rational use of surface and sub-surface (ground) water for irrigation. Bangladesh is a highly populated, agriculture based, country where natural processes like drought, rainfall, flood, etc. play significant roles on the hydrological and agro-environmental condition and the land-use therein. During the last few decades, intensification of land utilization for agriculture, large-scale expansion of ground-water irrigation, utilization of pesticides and fertilizers resulted in various hydro-environmental problems like ground-water declination, arsenic contamination, together with decreasing soil fertility, etc. over the area. Water is a basic component for sustaining life and directly related to agricultural, meteorological and hydrological conditions over an area. The availability and distribution of water over an area is a principal governing factor for agricultural production and in maintaining an ecological balance. The study of hydrological conditions of an area is of vital importance for rational planning and proper agricultural management. The lack of up to date baseline information concerning the aquatic conditions over a region throughout the year is a fundamental problem associated with proper planning and sustainable development of agriculture over an area. The current research involves a study on land and water related issues, over a part of Teesta Barrage Project situated in the north-eastern region of Bangladesh, an area subject to various climatic compulsion and human intervention. Teesta Barrage Project went into operation in 1993 and the supplementary irrigation was started in 2000. The main purpose of this project was to provide the supplementary irrigation to increase the crop production (Rahman, 2011). The specific objective of this study was to assess the irrigation potentiality for over an area using Remote Sensing and Geographic Information System. To realize the above stated specific themes the following objectives were taken into consideration:

(i) Identify the natural sources of surface water;

(ii) Identify the artificial sources of surface water;

(iii) Identify the existing irrigation systems;

(iv) Identify the water stressed areas;

(v) Suggest the areas for irrigation;

(vi) Monitoring the irrigated area for Boro rice cultivation; and

(vii) Trend analysis on the use ground water for irrigation.

2.

\section{DATA AND METHODOLOGY}

\subsection{STUDY AREA}

The study area is the Teesta Barrage Project Phase-2 Unit-1 of Bangladesh. The study area is located in 5 upazilas of 3 Districts of Rangpur Division in Bangladesh. Those are Badarganj and Taraganj upazilas of Rangpur district, Kishoregonj and Sayedpur upazilas of Nilphamari district and Parbatipur upazila of Dinajpur district. Figure 1 shows the study area.

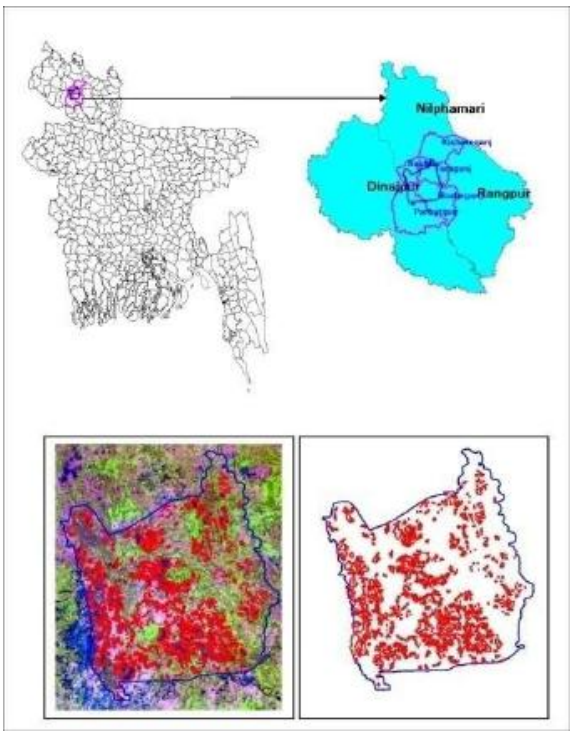

Figure 1: Location map of the study area

The area extends from N $25^{\circ} 38^{\prime \prime} 43.52^{\prime}$ to N $25^{\circ} 50^{\prime} 46.33^{\prime \prime}$ and E $88^{\circ} 52^{\prime} 27.21^{\prime \prime}$ to E $89^{\circ} 04^{\prime} 20.08^{\prime \prime}$ and is and is about $335 \mathrm{~km}$ away from the capital city of Dhaka. In terms of Agro Ecological Zones the study area is located in 'Active Teesta Floodplains' of Teesta, Korotoa and Jameneshawari rivers. It has complex patterns of 
low, generally smooth ridges, inter-ridge depressions, river channels and cut-off channels. In Rangpur, the average annual temperature is $24.9^{\circ} \mathrm{C}$. The average annual rainfall is $2192 \mathrm{~mm}$. The least amount of rainfall occurs in December. The average in this month is $3 \mathrm{~mm}$. The greatest amount of precipitation occurs in June, with an average of $481 \mathrm{~mm}$. The temperatures are highest on average in August, at around $29.0{ }^{\circ} \mathrm{C}$. The lowest average temperatures in the year occur in January, when it is around $17.3{ }^{\circ} \mathrm{C}$. The variation in the precipitation between the driest and wettest months is $478 \mathrm{~mm}$. The variation in temperatures throughout the year is $11.7^{\circ} \mathrm{C}$. (https://en.climate-data.org/asia/bangladesh/rangpur-division/rangpur-4997/)

\subsection{DATA USED}

Cloud-free Landsat 8 Operational Land Imager (OLI) data of October 2016, November 2016, December, 2016, January, 2017, February, 2017, March 2017 and April, 2017 have been downloaded form United States Geological Survey (USGS) website (USGS, 2017). Extraction of different bands data has been done and then layer stacking of has been conducted for making the multi bands images. Bands 2 to 7 were considered for layer stacking. Besides these, historical maps and ground water level data of this area have also been used.

\subsection{METHODOLOGY}

On screen digitization has been performed to delineate the water bodies and irrigation channels and the time sequential irrigated areas. Global Positioning System (GPS) based ground verification (Figure 2) has also been conducted in different time to delineate accurately the interested area classes in the study area (Figure 3). Ground photographs have also been taken during ground truthing. The whole methodology of the study has been shown in Figure 4.



Figure 2: GPS based ground truthing and data collection

3.

\subsection{Identifying the Natural Sources of Surface Water}

The natural source of surface water of the study area has been shown in Figure 5a. The Landsat 8 OLI image of 7 December 2016 has been used to identify the natural sources of surface water. Beels, canals and rivers are belonging to this group. The total area of Rivers \& natural canals and beels and canals and rivers are 613.12 and 19.13 ha respectively. It has been observed and received information from local peoples that the area became shrinkage river bed lifted up due to siltation. People also made dam across the natural canal for fish cultivation which has hampered the natural flow of water. Farmers cultivated Boro rice using the natural water from beels but later on it is not sufficient to the end of the crop life cycle.

Landsat 8 OLI data has been downloaded from USGS website. Band 2-7 were selected for Layer Stacking and then data screening has been done for selecting cloud free data. Geometric distortions were checked among the satellite images and image-to-image geometric correction was applied where the images are not properly 
matched. Spectral analysis, interpretation on-screen digitization has been done for identification of natural and artificial sources of water for irrigation in the study area. Normalized Difference Water Index (NDWI) and Normalized Difference Vegetation Index (NDVI) were calculated for identifying the suggested area for irrigation. Time sequential images (January, February and March) were analyzed for monitoring the irrigated area for Boro rice cultivation. Groundwater level data collected during ground trothing were also analysis for trend analysis of water level during the growing season.

Field verification will be conducted to check the accuracy of analyzed data in the laboratory. Confusing / area of interest were identified in the analyzed map with respective coordinates then went to the field with those maps GPS device for cross checking the analyzed results. Ground photographs were also taken in different times of investigation.



Figure 4: Shows the whole methodology of the research

\subsection{Identifying the Artificial Sources of Surface Water}

The artificial source of surface water of the study area has been shown in Figure $5 \mathrm{~b}$. The Landsat 8 OLI image of 7 December 2016 has been used to identify the artificial sources of surface water. Ponds, reservoirs, main canal and secondary canals of Teesta Barrage irrigation project are belonging to this group. The total area of ponds, artificial main canal and artificial secondary canals are 213.49, 155.78 and 10.82 ha respectively. The length of the artificial main canal and artificial secondary canals are 34.77 and $7.17 \mathrm{~km}$ respectively. In the study area the main irrigation canal introduced at the top right corner and ended up at the bottom left. The secondary canal started near Taraganj Bus stoppage crossed the Taraganj Burirhat road and ended up near Burirhat Challia. Both the canals are not under operation in full swing hence people temporarily doing aquaculture.

\subsection{Identifying the Existing Irrigation Systems}

The existing irrigation systems of the study area have been shown in Figure 5c. The Landsat 8 OLI image of 7 December 2016 has been used to identify the existing irrigation systems. Ponds, beels, rivers, natural canals, artificial main canal and artificial secondary canals of Teesta Barrage irrigation project are belonging to this group. Basically, natural sources of water are using for irrigation; artificial sources are yet to be started. But it has the potential to bring more area under irrigation. However, still the ground water source is the backbone of the irrigation system which has been observed during ground truthing. Identification of ground water source for irrigation was excluded from our study but the irrigated area in the study was monitored during the boro crop cultivation using time series satellite data. However, the trend analysis on the use of ground water level was monitored using secondary data source. Being ground water irrigation systems are very popular but it is not sustainable. So, this system should bring in least proportion of the irrigation system as early as possible. 

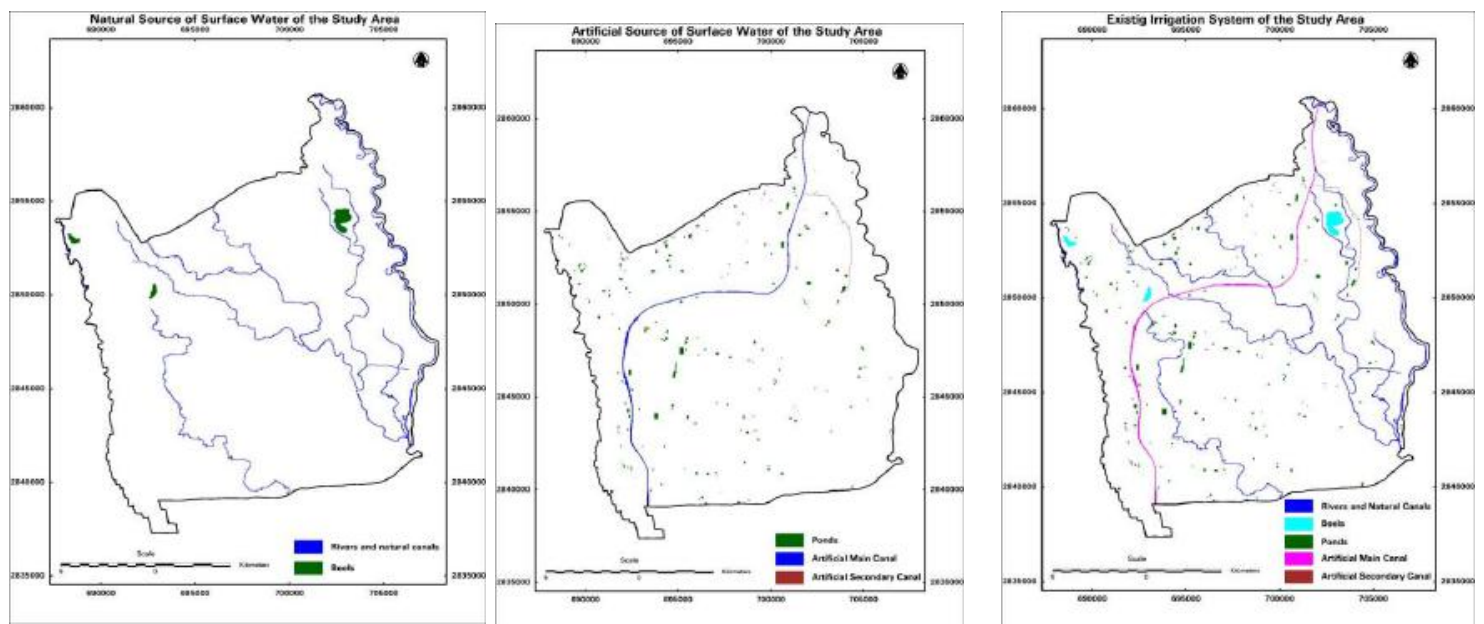

Figure 5: Shows the (a) natural source of surface water, (b) artificial source of surface water and (c) existing irrigation system of the study area

\subsection{Identifying the Water Stressed Areas}

Different indexing calculations have been done from images of Landsat 8 OLI. Remotely sensed NDWI is a good measure of moisture condition at landscape (Reflectance values for the green and the near infrared bands (0.533-0.590 $\mu \mathrm{m}$ and $0.851-0.879 \mu \mathrm{m}$ respectively) were used to calculate the NDWI.



Figure 6: (a) NDWI and (b) NDVI Based Map of the Study Area

NDWI has been calculated by using the following formula:

$$
N D W I=\frac{\text { Band } 3-\text { Band } 5}{\text { Band } 3+\text { Band } 5}
$$

Remotely sensed NDVI is a good measure of vegetation activity at landscape. Reflectance values for the red and the near infrared bands $(0.636-0.673 \mu \mathrm{m}$ and $0.851-0.879 \mu \mathrm{m}$ respectively) were used to calculate the NDVI. NDVI has been calculated by using the following formula:

$$
N D V I=\frac{\text { Band } 5-\text { Band } 4}{\text { Band } 5+\text { Band } 4}
$$

The water stressed areas have been calculated using NDWI and NDVI are shown in Figures 6(a-b) respectively. 
Comparison has been done to find the relation between the land categories of NDVI and NDWI in Figures 7(ab). Interpretations on both categories have been done to infer the suggested area for irrigation. In Figure 7a there are two categories of bare land. They are Bare land 1 and Bare land 2 which are shown in colour cyan and tan respectively. In Bare land 1 there are few sparse vegetation on the other hand Bare land 2 is absolutely barren. In Figure $7 b$ there are two classes such as Moist land and Dry land which are corresponding to the classes of Bare land 1 and Bare land 2 respectively of Figure 7a. Therefore, in Figure $7 \mathrm{~b}$ the Moist land and Dry land have been shown in colour grey and yellow respectively and both the areas shall be brought under irrigation.
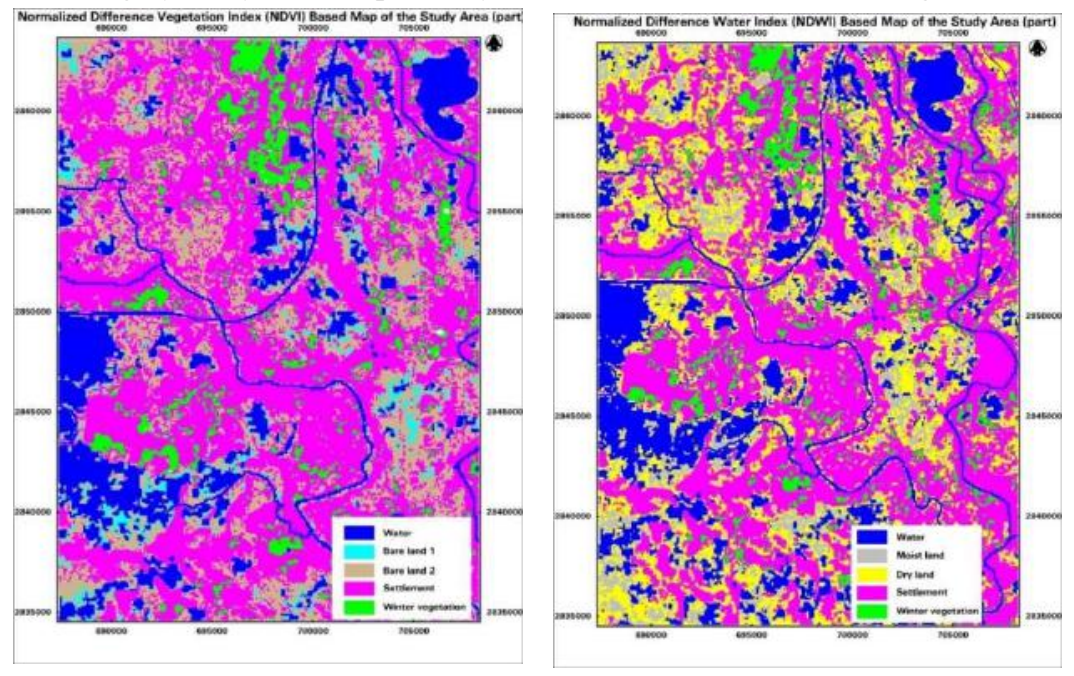

Figure 7: (a) NDVI and (b) NDWI Based Map of the Study Area (part)

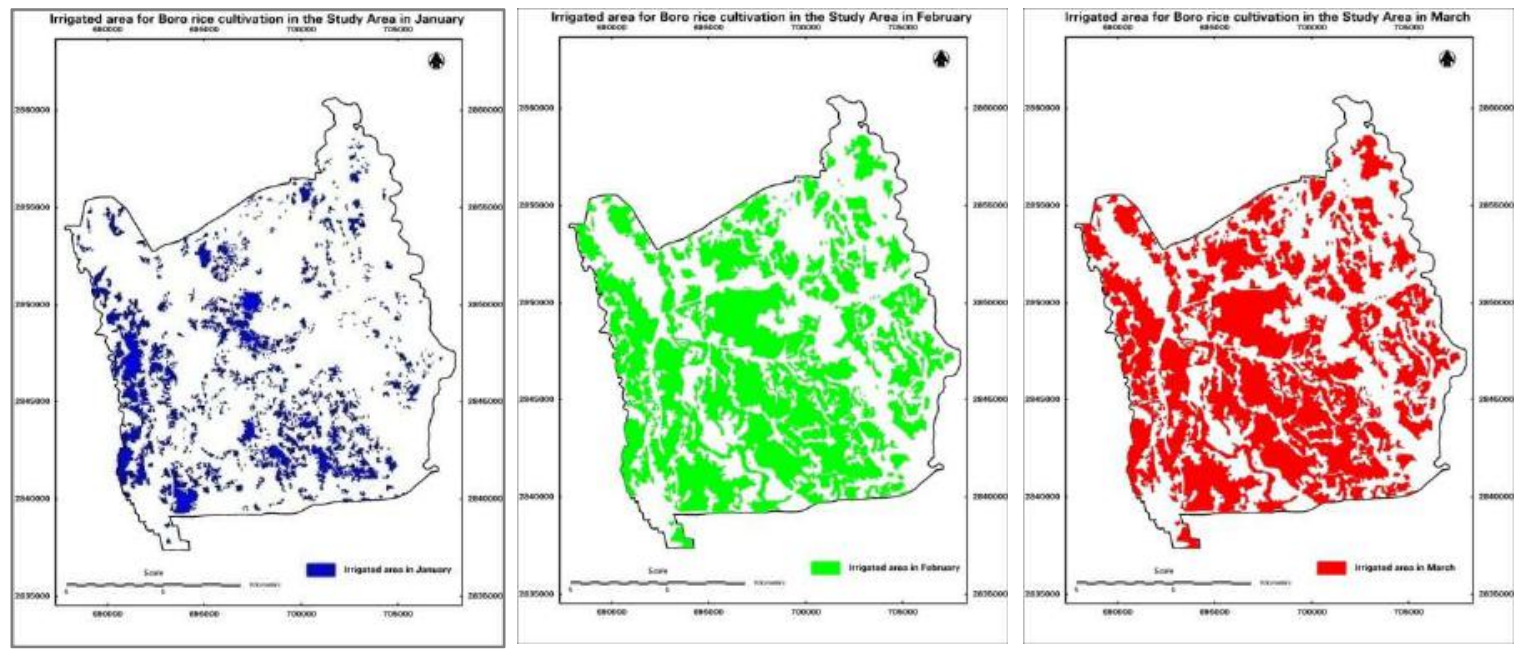

Figure 8: Irrigated Area for Boro cultivation in the Study Area in (a) January, (b) February and (c) March

3.6

Monitoring the Irrigated Area for Boro rice cultivation

The Landsat 8 OLI image of 24 January 2017, 25 February 2017 and 13 March 2017 has been used to monitor the irrigated area for Boro rice cultivation. The irrigated area for the above months has been shown in Figures 8(a-c). Irrigation for Boro cultivation mainly stared from January, triggered in February and saturated in March. The irrigated area statistics for January, February and March are 4563.28, 13583.73 and 13757.24 ha respectively.

\subsection{Trend Analysis on the Use Ground Water for Irrigation}

Boro rice cultivation is completely dependent on irrigation. Source of irrigation may be from existing natural source of water or ground water. Although the use of natural source of water is eco-friendly and sustainable but the source is not available round the year. On the other hand, source of ground water is limited and usage of this 
has to be rational but still it is the main source of irrigation. Ground water level data from secondary source has been collected and trend analysis has been done from the month of January to July at $16^{\text {th }}$ days except February and results shown in figure 9. In January water level was 3 to 4 meters but it goes down to least level of 9.25 meter in March. It started to rise gradually from April and mounted in July at 7.15 meter. During April to June it fluctuated from 8.9 meter to 7.25 meter. The groundwater level data used for this analysis has been collected from secondary source during ground truthing (field verification of remote sensing analyzed data) in the study area. Bangladesh Agricultural Development Corporation (BADC) upazila office collects this data regularly from their bore hole pipes measurement during the season. It is alarming phenomenon of more depending on using ground water for irrigation, which may cause detrimental effect on environment as desertification.

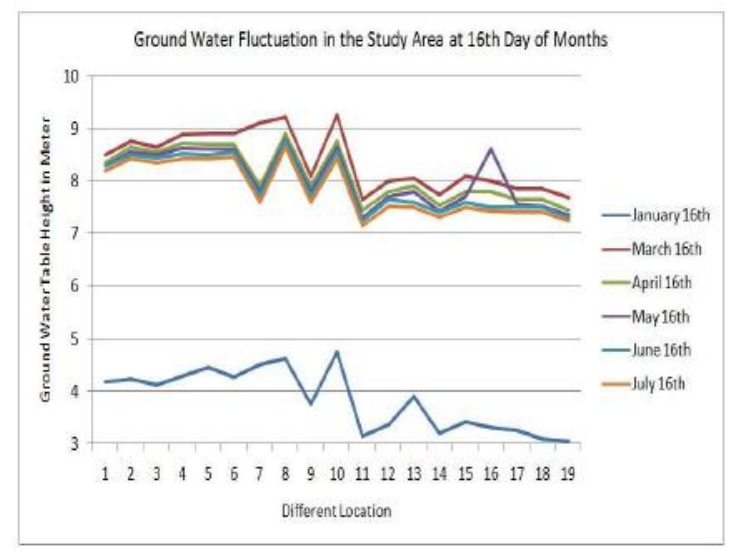

Figure 9: Ground water fluctuation from January to July except February in the study area (BADC, 2017)

\section{CONCLUSIONS}

The natural and artificial sources of irrigation water of the study area have been investigated. Hence the existing irrigation system has also been identified. Water stressed area was calculated and suggested area to be irrigated has been inferred. Results from this study could be used by the agricultural extension department field workers and build awareness to the farmers about the timing and fields of irrigation to avoid the over and under uses of water for irrigation. Monitoring irrigated area for Boro rice cultivation was also investigated round the crop growing season. It has been found that the maximum water for irrigation is required in the month of February to March. From the secondary data it was observed that the over exploitation of ground water for Boro rice irrigation is the prime cause of ground water depletion. It is recommended that the operational work of the adopted Teesta Barrage Irrigation Phase in our study area should be started at earliest convenient to ease the pressure on ground water for Boro rice irrigation.

\section{ACKNOWLEWDGEMENT}

The authors are thankful to Bangladesh Space Research and Remote Sensing Organization (SPARRSO) for the encouragement extended for this study.

\section{REFERENCES}

ADB-The Asian Development Bank, 2005. Water for All. The Water Policy for Asian Development Bank, http://www.google.com.sg/search.ADB org.html.

BADC, 2017. Groundwater Data Recording Log Book, Bangladesh Agricultural Development Corporation (BADC), Parbatipur, Dinazpur.

BBS 2015. Statistical Year Book of Bangladesh 2015, Bangladesh Bureau of Statistics, Statistics and Informatics Division, Ministry of Planning, p. 124-137.

BBS, 2017. Yearbook of Agricultural Statistics 2017, Bangladesh Bureau of Statistics, Statistics and Informatics Division, Ministry of Planning, p. 39

Gebeyehu, M. N., 2019. Remote Sensing and GIS Application in Agriculture and Natural Resource Management, International Journal of Environmental Sciences \& Natural Resources, 19(2) DOI: 10.19080/IJESNR.2019.19.556009.

Islam, M. F., and Akman W., 2007. Changes in Socio-economic and Environmental Situations in the Dalia Irrigation Project Area During 2000-2007: Policy Recommendations, Journal of Bangladesh Studies, 3(1), 32-38. 
Hasana, M. Y., Khan M. F. H., Islam M. K., Hasan M. M., Hossain M. A., Monir M. U., Samad M. A., and Ahmed M. T., 2020. Dataset on the evaluation of hydrochemical properties and groundwater suitability for irrigation purposes: South-western part of Jashore, Bangladesh, ELSEVIER Groundwater for Sustainable Development, 11, 2020.

Mohammadi, N. K., 2019. A Review on GIS in Irrigation and Water Management, International Journal of Engineering Research \& Technology (IJERT), ISSN: 2278, 8(05).

Rahman, E. M., 2011. Effect of Teesta Barrage project on Aman Rice Production, A project submitted to the Institute of Water and Flood Management (IWFM), Bangladesh University of Engineering and Technology, Dhaka.

Rahaman, M. F., Chowdhury S. J., Arefin R, and Quamrul H. M., 2019. Groundwater potentiality study in drought prone barind tract, NW Bangladesh using remote sensing and GIS, ELSEVIER Groundwater for Sustainable Development, 8, 205-215.

Sarker, D.C., Pramanik B.K., Zerin A.I., and Ara I., 2011. Climatic Impact Assessment: A Case Study of Teesta Barrage Irrigation Project in Bangladesh, International Journal of Civil \& Environmental Engineering (IJCEE), 11(1).

Taghvaeian, S., Neale C. M. U., John C. O., Sritharan I. S., and Watts R. D., 2018. Remote Sensing and GIS Techniques for Assessing Irrigation Performance: Case Study in Southern California, Journal of Irrigation and Drainage Engineering, ISSN 0733-9437, DOI:10.1061/(ASCE)IR.1943-4774.0001306, 144(6), https://en.climate-data.org/asia/bangladesh/rangpur-division/rangpur-4997/

USGS 2017. https://earthexplorer.usgs.gov/

(C) 2020 The Authors. Journal of Engineering Science published by Faculty of Civil Engineering, Khulna University of Engineering \& Technology. This is an open access article under the terms of the Creative Commons AttributionNonCommercial-NoDerivatives License, which permits use and distribution in any medium, provided the original work is properly cited, the use is non-commercial and no modifications or adaptations are made. 